\title{
Asas Akusator Dalam Perlindungan Hukum Atas Hak Tersangka Berdasarkan Undang-Undang Nomor 8 Tahun 1981 Tentang Kitab Undang-Undang Hukum Acara Pidana
}

\author{
Margo Hadi Pura1, Hana Faridah ${ }^{2}$ \\ ${ }^{12}$ Universitas Singaperbangsa Karawang \\ Email: hadipura23@gmail.com, hana.faridah@fh.unsika.ac.id
}

Received : 16 Mar 2021| Revised : 15 Apr 2021| Accepted : 2 May 2021| Published : 10 Jun 2021

\begin{abstract}
Law enforcement in general can be interpreted as the application of law in various aspects of the life of the nation and state in order to create legal order and legal certainty that is oriented towards justice. In the Indonesian procedural law, Law Number 8 of 1981 contains regulations for law enforcement officers, namely, investigators, public prosecutors and judges in exercising their authority to enforce material criminal law (KUHP). In this study using a normative juridical approach. In this approach method examines legal problems based on normative rules whether it is in accordance with people's lives. The human rights system includes within the realm of judicial administration, which contains several principles, namely fair trial (fair trial), judicial independence and effective remedies. These principles apply not only to general criminal justice and military criminal justice. In Law No. 39 of 1999, it emphasizes investigation rather than investigation. In the practice of upholding the rule of law, there is still no good cooperation between law enforcers, the community and the government. To ensure respect and protection of human rights in the criminal justice process, the function of legal advisers is very important as a companion to suspects and defendants in order to defend their rights. These rights are regulated in Chapter VI (Article 50 to Article 68) Law Number 8 Year 1981. Legal protection for suspects from actions involving the suspect's human rights by investigators is very important. To protect suspects from arbitrary actions by investigators, the Criminal Procedure Code regulates the protection of human rights, particularly in relation to the rights of suspects and defendants. To avoid obstacles that occur at the investigation level, the investigator must inform him of the right to legal aid, and other rights.
\end{abstract}

Keywords: Law Enforcement, Criminal Procedure Law, Investigation

\begin{abstract}
ABSTRAK
Penegakan hukum secara umum dapat diartikan sebagai penerapan hukum di berbagai aspek kehidupan berbangsa dan bernegara demi mewujudkan ketertiban dan kepastian hukum yang berorientasi kepada keadilan. Dalam Hukum Acara Indonesia Undang-Undang Nomor 8 Tahun 1981 di dalamnya memuat pengaturan para aparat penegak hukum yaitu, Penyidik, Penuntut Umum dan Hakim mengenai dalam menjalankan wewenangnya menegakkan hukum pidana materiil (KUHP). Pada penelitian ini menggunakan pendekatan yuridis normatif. Pada metode pendekatan ini mengkaji permasalahan hukum berdasarkan aturan normatif apakah sesuai dengan kehidupan masyarakat. Sistem hak asasi manusia mencakup didalamnya ranah administrasi peradilan, yang memuat beberapa prinsip, yaitu peradilan yang
\end{abstract}


adil (Fair Trial), Indepedensi Pengadilan dan pemulihan secara efektif. Prinsip-prinsip tersebut tidak hanya berlaku untuk peradilan pidana umum maupun peradilan pidana militer. Dalam Undang-Undang Nomor 39 Tahun 1999, lebih menekankan penyelidikan dibanding penyidikan. Di dalam praktik penegakan supremasi hukum masih belum ada kerja sama yang baik antara penegak hukum, masyarakat dan pemerintah. Untuk menjamin penghormatan dan perlindungan HAM dalam proses peradilan pidana, fungsi penasihat hukum sangat penting sebagai pendamping tersangka dan terdakwa agar mempertahankan hak-haknya. Hak-hak tersebut diatur dalam Bab VI (Pasal 50 sampai dengan Pasal 68) Undang-Undang Nomor 8 Tahun 1981. Perlindungan hukum bagi tersangka dari tindakan yang menyangkut hak asasi tersangka oleh penyidik sangatlah penting. Untuk melindungi tersangka dari tindakan penyidik yang sewenang-wenang maka dalam KUHAP diatur mengenai perlindungan Hak Asasi Manusia khususnya terkait dengan hak tersangka dan terdakwa. Untuk menghindari hambatan-hambatan yang terjadi di tingkat penyidikan, penyidik harus memeritahukan kepadanya tentang hak mendapat bantuan hukum, dan hak lain sebagainya.

Kata Kunci: Penegakan Hukum, Hukum Acara Pidana, Penyidikan

\section{PENDAHULUAN}

Republik Indonesia merupakan negara hukum yang berdasarkan Pancasila dan Undang-Undang Dasar 1945. Adapun makna dari negara hukum yaitu bahwa hukum di negara ini ditempatkan pada posisi yang strategis di dalam konstelasi ketatanegaraan. ${ }^{1}$ Penegakan hukum secara umum dapat diartikan sebagai penerapan hukum di berbagai aspek kehidupan berbangsa dan bernegara demi mewujudkan ketertiban dan kepastian hukum yang berorientasi kepada keadilan. Secara khusus penegakan hukum dapat diartikan sebagai rangkaian kegiatan di dalam sistem peradilan (pidana) yang bersifat preventif, represif, dan edukatif. Penegakan hukum merupakan bagian dari pembangunan hukum yang merupakan komponen integral dari pembangunan nasional.

Dalam menegakkan dan mewujudkan kepastian hukum, tindakan aparatur penegak hukum secara formal harus ada pengaturannya, agar tindakannya tidak kontradiktif dengan undang-undang. Artinya, tidak hanya mengacu kepada ketentuan hukum pidana materiil, tetapi juga mengacu kepada hukum pidana formal, yang lazim disebut Hukum Acara Pidana. Hukum Acara Pidana merupakan hukum formal yang di dalamnya memuat ketentuan-ketentuan tentang bagaimana suatu proses beracara dalam rangka penegakan hukum pidana (hukum materiil). Dalam ketentuan Hukum Acara Pidana dijabarkan bagaimana proses penangkapan suatu kasus pidana mulai dari penyelidikan, penyidikan, penuntutan hingga proses pengadilannya. Pengertian hukum acara pidana salah satunya menurut Wiryono Prodjodikoro: "hukum acara pidana berhubungan erat dengan adanya hukum pidana maka dari itu merupakan suatu rangkaian peraturan-peraturan yang memuat cara bagaimana badan-badan pemerintah yang berkuasa yaitu Kepolisian, Kejaksaan, dan Pengadilan harus bertindak guna mencapai tujuan negara dengan mengadakan hukum pidana". ${ }^{2}$ Berbicara mengenai perlindungan hukum tentu sangat erat kaitannya dengan Hak Asasi Manusia (HAM). Di dalam Kamus Hukum dijelaskan, Hak Asasi Manusia adalah hak yang dimiliki

${ }^{1}$ Pasal 1 ayat 3 Undang-Undang Dasar 1945 setelah amandemen ketiga yang secara tegas menyatakan bahwa "Negara Indonesia adalah Negara Hukum".

${ }^{2}$ Wiryono Prodjodikoro, 1967, Hukum Acara Pidana di Indonesia, Penerbit Sumur Bandung, Jakarta, hlm. 13 . 
manusia karena kelahirannya, bukan karena diberikan oleh masyarakat atau negara. ${ }^{3}$ Dalam melindungi hak warga negara dan menciptakan proses hukum yang adil mencakup sekurang-kurangnya:

1. Perlindungan dari tindakan sewenang-wenang dari pejabat negara;

2. Pengadilan yang berhak menentukan salah tidaknya tersangka atau terdakwa;

3. Sidang Pengadilan harus terbuka untuk umum (tidak boleh bersifat rahasia);

4. Tersangka dan terdakwa harus diberikan jaminan-jaminan untuk dapat membela diri sepenuhnya. ${ }^{4}$

Mencari kesalahan senantiasa menggugah perbuatan dan pemikiran subyektif dan karena itu pula sering kali menimbulkan kesempatan bagi pemeriksa yang sadistis untuk menggunakan kekuatan fisik daripada seharusnya menggunakan akal sehat. Jika kekerasan fisik digunakan terhadap penjahat yang benar-benar telah melakukan kejahatan, mungkin dapat dipertimbangkan bahwa kekerasan yang diterimanya adalah seimbang dengan atau merupakan bagian dari hukuman yang harus dikenakan kepadanya. Akan tetapi, sesuatu pemeriksaan dengan kekerasan fisik yang hanya didasarkan pada prasangka subyektif akan merupakan suatu tantangan terhadap keadilan itu sendiri, merupakan ketidak adilan pelaksanaan hukum. ${ }^{5}$

Dalam Hukum Acara Indonesia Undang-Undang Nomor 8 tahun 1981 di dalamnya memuat pengaturan para aparat penegak hukum yaitu, Penyidik, Penuntut Umum dan Hakim mengenai dalam menjalankan wewenangnya menegakkan hukum pidana materiil (KUHP). Advokat adalah orang yang berprofesi memberi jasa hukum, baik di dalam maupun di luar pengadilan yang memenuhi persyaratan berdasarkan ketentuan Undang-undang ini. ${ }^{6}$ Dalam kaitan inilah pemberian hak-hak kepada tersangka oleh KUHAP tadi menjadi relevan. Akan tetapi, dalam pelaksanaanya belum berjalan secara optimal, terlebih bagi mereka yang buta akan hukum. Sehingga tidak di dapatkannya hak-hak mereka sebagai tersangka pada perkara pidana. Untuk itu, harus lebih diperhatikan kembali mengenai hak-hak tersangka yang telah diatur didalam Undang-Undang Nomor 8 Tahun 1981 tentang Kitab Undang-Undang Hukum Acara Pidana (KUHAP) agar tidak diabaikan atau dikurangi oleh penegak hukum dalam setiap pemeriksaan khususnya dalam pemeriksaan di tingkat penyidikan.

\section{METODE PENELITIAN}

Pada penelitian ini menggunakan pendekatan yuridis normatif. Pada metode pendekatan ini mengkaji permasalahan hukum berdasarkan aturan normatif apakah sesuai dengan kehidupan masyarakat. Untuk mendapatkan data dan informasi yang dimaksud oleh jurnal ini maka penulis menggunakan sifat penelitian analisis kualitatif. Penelitian ini menguraikan atau mendeskripsikan data yang diperoleh secara

\footnotetext{
${ }^{3}$ B.N. Marbun, Kamus Hukum Indonesia Edisi Kedua Direvisi, Cetakan 1, Jakarta: Pustaka Sinar Harapan, 2009, hlm. 29.

4 Mien Rukmini, Perlindungan HAM Melalui Asas Praduga Tidak Bersalah dan Asas Persamaan Kedudukan dalam Hukum pada Sistem Peradilan Pidana Indonesia, Bandung: Alumni, 2003, hlm. 32.

5 Gerson W. Bawengan, Penyidikan Perkara Pidana dan Teknik Interogasi, Jakarta: PT. Pradnya Paramita, 1977, hlm. 46.

6 Pasal 1 angka 1 Undang-Undang Nomor 18 Tahun 2003 Lembaran Negara (LN) Tahun 2003 Nomor 48 Tambahan Lembaran Negara (TLN) Nomor 4288 Tentang Advokat.
} 
normatif lalu diuraikan untuk mendeskripsikan data yang dikumpulkan secara sistematis. Bahan hukum primer yakni bahan-bahan hukum yang mengikat dan terdiri dari aturan-aturan normatif yang berkaitan dengan permasalahan hukum yang ada. Teknik pengumpulan data yang dilakukan dengan cara penelitian studi kepustakaan (library research), yaitu penelitian yang dilakukan dengan cara meneliti bahan pustaka atau yang disebut dengan data sekunder. Analisa data yang dilakukan dalam penelitian ini yaitu menggunakan data kualitatif. Metode analisa data kualitatif ini digunakan agar penulis dapat lebih tertuju dalam memahami dan menelaah bahan -bahan hukum serta perundang undangan yang berhubungan dengan topik yang menjadi judul dalam penulisan ini.

\section{PEMBAHASAN}

\section{A. Hak-Hak Tersangka dalam Perundang-undangan Sistem Peradilan di Indonesia}

Pokok pangkal pemeriksaan di hadapan penyidik ialah tersangka, dari tersangkalah diperoleh keterangan tentang peristiwa pidana yang sedang diperiksa. Akan tetapi, sekalipun tersangka yang menjadi titik tolak pemeriksaan, terhadapnya harus diberlakukan asas akusator. Tersangka harus ditempatkan pada kedudukan manusia yang memiliki harkat martabat. Dia harus dinilai sebagai subjek, bukan sebagai objek. ${ }^{7}$

Tersangka berdasarkan Pasal 1 angka 14 KUHAP adalah, seseorang yang karena perbuatannya atau keadaanya, berdasarkan bukti permulaan patut diduga sebagai tersangka yang dituntut, diperiksa dan diadili, di sidang pengadilan. Selanjutnya, terpidana berdasarkan Pasal 1 angka 32 KUHAP adalah seorang yang dipidana berdasarkan putusan pengadilan yang telah memperoleh kekuatan hukum tetap. Istilah perlindungan hukum yang dikemukakan dalam penulisan ini Negara untuk menghormati, melindungi, menegakkan dan memajukan hak-hak asasi manusia berdasarkan undang-undang dan peraturan hukum. ${ }^{8}$

Tersangka atau terdakwa diberikan seperangkat hak-hak oleh KUHAP mulai dari Pasal 50 sampai dengan Pasal 68 dan pasal-pasal lainnya. Hak-hak itu meliputi berikut ini: ${ }^{9}$

a. Hak untuk segera diperiksa, diajukan ke pengadilan dan diadili (Pasal 50 ayat (1), (2), (3) KUHAP).

b. Hak untuk mengetahui dengan jelas dan bahasa yang dimengerti olehnya tentang apa yang disangkakan dan apa yang didakwaakan (Pasal 51 butir a dan b KUHAP).

c. Hak untuk memberikan keterangan secara bebas kepada penyidik dan hakim Pasal 52).

d. Hak untuk mendapat juru bahasa (Pasal 53 ayat 1).

e. Hak untuk mendapat bantuan hukum pada setiap tingkat pemeriksaan (Pasal 54 KUHAP). Ini berarti bahwa. Oleh karena hanya merupakan hak,

\footnotetext{
${ }^{7}$ Tioneni Sigiro, Pelaksanaan Asas Akusator Oleh Polri Dalam Penyidikan Tindak Pidana Di Polres Dairi, Jurnal Fakultas Hukum Universitas Sumatera Utara Medan 2018, hlm 5.

${ }^{8}$ Penjelasan Pasal 1 angka 14 dan KUHAP.

${ }^{9}$ Lilik Mulyadi, Hukum Acara Pidana Indonesia Suatu Tinjauan Khusus Terhadap Surat Dakwaan, Ekssepsi Putusan Hakim, Citra Aditya Bakti, Bandung, 2012, hlm .41.
} 
mendapatkan bantuan hukum masih tergantung kepada kemauan tersangka atau terdakwa. Dia dapat mempergunakan hak tersebut, tapi bisa juga tidak mempergunakan hak itu. Konsekuensinya, tanpa didampingi oleh penasihat hukum, tidak menghalangi jalannya.

f. Tersangka atau tersangka berhak untuk memilih sendiri penasihat hukumnya.

g. Hak tersangka atau terdakwa yang berkebangsaan asing untuk menhubungi dan berbicara dengan perwakilan negaranya (Pasal 57 ayat 2).

h. Hak menghubungi dokter bagi yang ditahan (Pasal 58)

i. Hak untuk diberitahu kepada keluarganya atau orang lain yang serumah (Pasal 59 dan 60)

j. Hak untuk dikunjungi sanak keluarga, untuk kepentingan pekerjaan atau keluarga (Pasal 61)

k. Hak untuk berhubungan surat menyurat dengan penasihat hukumnya (Pasal 62).

1. Hak untuk menghubungi atau menerima kunjungan rohaniawan (Pasal 63)

m. Hak untuk mengajukan saksi dan ahli yang menguntungkan (a de charge) (Pasal 65).

n. Hak untuk minta banding, kecuali putusan bebas dan lepas dari segala tuntutan hukum (Pasal 67).

o. Hak menuntut ganti kerugian (Pasal 68).

p. Hak untuk ingkar terhadap hakim yang mengadili (Pasal 27 (1) UU Pokok Kekuasaan Kehakiman).

q. Hak keberatan atau penahan atau jenis penahanan.

r. Hak keberatan atas perpanjangan penahanan (Pasal 29 ayat 7).

Pengaturan lebih lanjut mengenai persamaan kedudukan di hadapan hukum sebagaimana ditegaskan dalam beberapa ketentuan Pasal UUD 1945 tersebut dapat dilihat dalam UU No. 48 Tahun 2009 tentang Kekuasaan Kehakiman, UU No. 39 Tahun 1999 tentang HAM dan UU No. 8 Tahun 1981 tentang KUHAP. Pasal 8 UU No. 48 Tahun 2009 tentang Kekuasaan Kehakiman secara eksplisit menyatakan bahwa: "Setia orang, yang disangka, ditangkap, ditahan, dituntut dan / atau dihadapkan di depan pengadilan, wajib dianggap tidak bersalah sebelum adanya putusan pengadilan yang menyatakan kesalahannya dan memperoleh kekuatan hukum yang tetap."

Implementasi Hak Asasi Manusia secara tersirat sebenarnya sudah diakui dalam Undang-Undang Republik Indonesia No. 8 Tahun 1981 tentang hukum acara pidana (KUHAP). Menurut ketentuan Pasal 117 Ayat 1, "keterangan tersangka dan atau saksi kepada penyidik diberikan tanpa tekanan dari siapapun dan atau dalam bentuk apapun." Artinya dengan adanya Pasal tersebut, pemeriksaan oleh penyidik untuk kepentingan penyidikan harus sesuai dengan hukum yang ada dan menghormati Hak Asasi Manusia (HAM). Selain itu, pemuatan hak asasi dalam tugas kepolisian sebagai penyidik, juga ditegaskan dalam Pasal 4 Undang-undang Nomor 2 Tahun 2002 tentang Kepolisian, "Kepolisian Negara Republik Indonesia bertujuan untuk mewujudkan keamanan dalam negeri yang meliputi terpeliharanya keamanan dan ketertiban masyarakat, tertib dan tegaknya hukum, terselenggaranya perlindungan, 
pengayoman, dan pelayanan terhadap masyarakat, serta terbinanya ketenteraman masyarakat dan menjunjung tinggi Hak Asasi Manusia." Kemudian juga ditegaskan dalam Pasal 19 ayat 1 "bahwa polisi harus senantiasa bertindak berdasarkan norma hukum, dan mengindahkan norma agama, kesopanan, dan kesusilaan dan menjunjung tinggi HAM." Dalam kaitannya dengan wewenang polisi dalam melakukan pemeriksaan terhadap tersangka guna mendapatkan keterangan yang berkaitan dengan suatu tindak pidana. maka prinsip yang harus dipegang adalah berdasarkan Pasal 33 Undang-Undang Nomor 39 Tahun 1999 menegaskan "bahwa setiap orang berhak untuk bebas dari penyiksaan, penghukuman atau perlakukan yang kejam, tidak manusiawi, merendahkan derajat dan martabat kemanusiaan.

Kewenangan polisi sebagai penyidik harus memperhatikan prinsip-prinsip yang terkandung dalam Undang-Undang Hak Asasi Manusia (HAM) yaitu UndangUndang Nomor 39 tahun 1999, jika diuraikan secara sistematis sebagai berikut:

a) Setiap orang berhak atas pengakuan, jaminan, perlindungan, dan perlakuan hukum yang adil serta mendapat kepastian hukum dan perlakuan yang sama didepan hukum.

b) Setiap orang berhak atas perlindungan hak asasi manusia dan kebebasn dasar manusia, tanpa dikriminasi.

c) Setiap orang diakui sebagai manusia pribadi yang berhak menuntut dan memperoleh perlakuan serta perlindungan yang sama sesuai dengan martabat kemanusiaannya di depan hukum.

Sehubungan dengan hal tersebut, selama ini diberlakukannya Undang-undang No 8 Tahun 1981 tentang Hukum Acara Pidana (KUHAP), yang merupakan aturan dalam proses peradilan pidana atau proses penegakan hukum pidana, ternyata masih banyak terjadi kekurangan-kekurangan. Undang-Undang tersebut dirasakan belum dapat mengakomodasikan harapan para pencari keadilan, terutama mengenai asas praduga tidak bersalah (APTB) yang merupakan asas hukum yang penting dalam proses peradilan pidana. Dalam hal ini asas yang paling pokok dari prosedur peradilan pidana modern adalah asas praduga tidak bersalah (APTB). Pengaturan tentang ini telah ditetapkan dalam Deklarasi Universal hak asasi manusia tanggal 10 Desember 1948 dan juga dalam konvensi Internasional, perjanjian internasional tentang hak sipil dan hak politik (New York 1966). Walaupun demikian menurut Keijzer: "praduga tidak bersalah bukanlah semata-mata hasil dari instrument internasional tersebut, tetapi sejarahnya sudah lebih tua". Walaupun pengakuan umum tentang asas praduga tidak bersalah sudah tersebar luas, namun Pada kenyataannya masih sering terjadi penyimpangan-penyimpangan terhadap peraturan tersebut. ${ }^{10}$ Biasanya polisi, hakim dan penegak hukum lainnya cenderung memberikan pertanyaan-pertanyaan yang memojokkan terdakwa sehingga terdakwa merasa tertekan.

Kasus yang terjadinya pengabaian terhadap prinsip asas praduga tak bersalah seperti tampak pada pemberitaan beberapa media massa yang mengabarkan tentang keterlibatan beberapa oknum penegak hukum, mulai dari hakim, jaksa, kepolisian dan advokat dalam lingkaran praktik suap dan mafia peradilan yang telah mengakibatkan munculnya opini publik yang seolah-olah menghakimi tersangka dengan berbagai cercaan, sindiran dan bahkan cemoohan yang dialamatkan kepada para tersangka. Opini publik tersebut seolah-olah telah mendahului putusan pengadilan berkekuatan

${ }^{10}$ Samuel P. Huntington Joan Nelson. Partisipasi Politik Di Negara Berkembang, Jakarta. Rineka Cipta. 1994, hlm 62. 
hukum tetap dalam pembuktian kesalahan tersangka.Dalam kondisi ini, asas praduga tak bersalah telah dikesampingkan. Kasus berikutnya adalah penggunaan kekerasan oleh polisi dalam penegakan hukum pidana ternyata masih mengemuka. Indrayanto Seno adji mengemukakan bahwa perilaku sedemikian telah membudaya, terutama dalam penyidikan untuk mendapatkan pengakuan terdakwa. Hal ini terbukti dari catatan Kontras antara Juli 2005 - Juni 2006 sebanyak 140 kasus. Kasus lainnya adalah kematian Tjetje Tadjuddin dibogor dan Ahmad Sidiq di Situbondo dalam proses penyelidikan (2007), kasus kekerasan terhadap mahasiswa Universitas Nasional, pada 24 Mei 2008 yang berujung pada kematian, kekerasan dalam penyidikan pada Rimsan dan Rostin di Gorontalo sepanjang Mei-Juni 2008 yang dipaksa mengaku sebagai pembunuh anak (padahal bukan pelaku) yang berujung pada pemidanaan terhadapnya. Kasus Sengkon dan Karta Kasus ini terungkap pada saat masih menggunakan hukum acara pidana yang lama yaitu HIR. Sengkon dan Karta telah diperlakukan dengan sewenang-wenang melanggar HAM pada saat dilakukan pemeriksaan pendahuluan (penyidikan), penuntutan dan pemeriksaan di persidangan. Akibanya, Sengkon dan Karta yang tidak melakukan tindak pidana (pembunuhan), menjalani hukuman karena sejak proses penyidikan, penuntutan dan persidangan, para aparat (petugas) tidak memperhatikan hak asasi mereka. Akibatnya, akibatnya terjadi salah menghukum terhadap orangnya dan salah menerapkan hukum terhadapnya. Hal ini karena tidak diperhatikan dan ditegakkannya HAM. Penegak hukum telah melakukan upaya paksa yang berlebihan, yaitu menggunakan sistem pemeriksaan inkuisitor bukan akusator. Penelitian LBH Jakarta, juga memperlihatkan masih adanya kekerasan dalam penyelidikan diwilayah Polda DKI Jakarta. Kekerasan oleh penyidik/penegak hukum lainnya yang disebutkan diatas hanya sebagian kecil dari banyaknya kekerasan yang terjadi terhadap tersangka dan terdakwa. Hal tersebut diatas sangatlah bertentangan dengan asas praguga tidak bersalah (APTB) dan juga HAM. Kalau kita melihat mengenai konsep hukum tentang anti penyiksaan terhadap tersangka pidana. Penyiksaan/penganiayaan terhadap tersangka/terhukum pidana sangat bertentangan dengan prinsip-prinsip kemanusiaan dan peradaban yang baik, maka tindakan seperti itu pada prinsipnya dilarang oleh hukum di berbagai Negara, dengan berbagai cara dan alasan.

Indonesia sebagai Negara hukum yang berdasarkan Pancasila dan UndangUndang Dasar 1945, wajib memberikan perlindungan hukum terhadap warga masyarakatnya, sesuai pembukaan Undang-Undang Dasar 1945 alinea ke empat, yaitu "melindungi segenap bangsa Indonesia dan seluruh tumpah darah Indonesia". Perlindungan hukum berdasarkan Pancasila berarti pengakuan dan perlindungan harkat dan martabat manusia atas dasar nilai Ketuhanan, kemanusiaan, persatuan, permusyawaratan, serta keadilan sosial. Nilai-nilai tersebut melahirkan pengakuan dan perlindungan hak asasi manusia dalam wujudnya sebagai makhluk individu dan makhluk sosial dalam wadah Negara kesatuan yang menjunjung tinggi semangat kekeluargaan demi mencapai kesejahteraan bersama. Perlindungan Hak Asasi Manusia (HAM) memiliki sejarah panjang yang dimulai dari martabat alamiah dan hak-hak kemanusiaan yang sama dan tidak dapat dicabut. Pengakuan martabat dan hak-hak tersebut merupakan dasar kemerdekaan, keadilan dan perdamaian dunia. Sebagai istilah, martabat dan hak-hak kemanusiaan tersebut disebut sebagai HAM.

Preambule Deklarasi Universal HAM menyatakan bahwa perlindungan terhadap HAM harus dilaksanakan melalui sarana hukum, hal itu dinyatakan sebagai berikut: "Whereas it is essential, that human rights should be protected by the rule of law”. Hal tersebut dapat diartikan bahwa di tingkat Nasional masalah perlindungan 
HAM harus diatur lebih lanjut melalui sarana hukum. Tegasnya, Negara harus mengatur HAM dalam peraturan perundang-undangan dengan upaya legislasi nasional (legislative measures). Melalui sarana hukum diharapkan aspek kepastian hukum terhadap perlindungan HAM akan lebih terjamin. ${ }^{11}$

Pada amandemen kedua UUD 1945 ditetapkan penambahan bab baru, yaitu bab XA (Pasal 28 A sampai dengan Pasal $28 \mathrm{~J}$ ) yang mengatur Hak Asasi Manusia. Beberapa pasal diantaranya, mengatur mengenai perlindungan hukum terhadap diri pribadi manusia yang menjunjung tinggi prinsip; "equality before the law" (sesuai asas-asas hukum di dalam KUHAP), yaitu :

Pasal 28 A, berbunyi :

1) Setiap orang berhak untuk hidup serta berhak mempertahankan hidup dan kehidupannya.

Pasal 28 D, berbunyi :

1) Setiap orang berhak atas pengakuan, jaminan, perlindungan dan kepastian hukum yang adil serta perlakuan yang sama dihadapan hukum.

Pasal 28 G, berbunyi :

1) Setiap orang berhak atas perlindungan diri pribadi, keluarga, kehormatan, martabat, dan harta benda yang di bawah kekuasaannya, serta berhak atas rasa aman dan perlindungan dari ancaman ketakutan untuk berbuat atau tidak berbuat sesuatu yang merupakan hak asasi.

2) Setiap orang untuk bebas dari penyiksaan atau perlakuan yang merendahkan derajat martabat manusia dan berhak memperoleh suaka politik dari negara lain.

Pasal 28 I, berbunyi :

1) Hak untuk hidup, hak untuk tidak disiksa, hak kemerdekaan pikiran dan hati nurani, hak beragama, hak untuk tidak di perbudak, hak untuk diakui sebagai pribadi di hadapan hukum, dan hak untuk tidak dituntut atas dasar hukum yang berlaku surut adalah hak asasi manusia yang tidak dapat dikurangi dalam keadaan apapun.

2) Setiap orang berhak bebas dari perlakuan yang bersifat diskriminatif atas dasar apapun dan berhak mendapatkan perlindungan terhadap perlakuan yang bersifat diskriminatif itu.

Pasal $28 \mathrm{~J}$, berbunyi :

1) Setiap orang wajib menghormati hak asasi manusia orang lain dalam tertibkehidupan bermasyarakat, berbangsa, dan bernegara.

2) Dalam menjalankan hak dan kebebasannya, setiap orang wajib tunduk kepada pembatasan yang ditetapkan dengan undang-undang dengan maksud semata-mata untuk menjamin pengakuan serta penghormatan atas hak dan kebebasan orang lain dan untuk memenuhi tuntutan yang

11 Andrey Sujatmoko, Hukum HAM dan Hukum Humaniter. (Jakarta: PT RajaGrafindo Persada, 2015. hlm. 40. 
adil sesuai dengan pertimbangan moral, nilai-nilai agama, keamanan, dan ketertiban umum dalam suatu masyarakat demokratis.

Disebutkan pula, mengenai tanggungjawab pelaksanaan perlindungan hak ini, tercantum dalam Pasal 28 I ayat (4) dan ayat (5), yang berbunyi :

1) Perlindungan, pemajuan, penegakan, dan pemenuhan hak asasi manusia adalah tanggungjawab negara, terutama pemerintah.

2) Untuk menegakkan dan melindungi hak asasi manusia sesuai dengan prinsip Negara hukum yang demokratis, maka pelaksanaan hak asasi manusia dijamin, diatur, dan dituangkan dalam peraturan perundangundangan.

Hak-Hak Dasar :

1) terjemahan dari istilah grondrechten, fundamental rights;

2) hanya mempunyai kaitan erat dalam suatu negara bangsa/melalui hukum nasional;

3) konotasi hak-hak dasar jelas dan tegas, merupakan bagian tidak terpisahkan dari UUD (lebih ke aspek yuridis);

Hak-hak dasar sebagaimana yang ditetapkan dalam UUD 1945 yang berkaitan dengan kehidupan berkeadilan sosial, antara lain :

a. kesamaan kedudukan dalam hukum dan wajib menjunjung hukum;

b. kesamaan kedudukan dalam pemerintahan dan wajib menjunjung emerintahan tersebut;

c. berhak atas pekerjaan yang layak bagi kemanusiaan;

d. perekonomian merupakan usaha bersama atas dasar kekeluargaan;

e. penyelenggaraan produksi yang penting bagi negara, yang menguasai hajat hidup orang banyak;

f. kemakmuran masyarakat yang diutamakan dan bukan kemakmuran orang perseorangan;

g. fakir miskin dan anak terlantar dipelihara oleh Negara.

Menurut Undang-Undang Nomor 39 Tahun 1999 tentang Hak Asasi Manusia, hak yang harus dilindungi pemerintah terkait perlindungan hukum terhadap diri pribadi manusia atau tersangka yang menjalani proses pemeriksaan perkara pidana, antara lain:

1) Hak Perlindungan, Berhak atas perlindungan pribadi, keluarga kehormatan, martabat dan hak miliknya (Pasal 29 ayat (1) Undang-Undang No.39 Tahun 1999).

2) Hak Rasa Aman, Berhak atas rasa aman dan tentram serta perlindungan terhadap ancaman ketakutan untuk berbuat atau tidak berbuat sesuatu (Pasal 30 Undang-Undang No.39 Tahun 1999).

3) Hak Bebas dari Penyiksaan, Berhak untuk bebas dari penyiksaan, penghukuman atau perlakuan yang kejam, tidak manusiawi, merendahkan derajat dan martabat kemanusiaannya (Pasal 33 ayat (1) Undang-Undang No.39 Tahun 1999). 
4) Hak tidak diperlakukan Sewenang-wenang, Setiap orang tidak boleh ditangkap, ditahan, dikucilkan, diasingkan, atau dibuang secara sewenangwenang (Pasal 34 Undang-Undang No.39 Tahun 1999).

5) Hak tidak di Siksa, Berdasarkan hak-hak tersebut diatas, maka penyidik wajib menjamin terlaksananya hak-hak seseorang tersangka selama proses penyidikan berlangsung disinilah peran penyidik dalam memberikan jaminan pelaksanaan hak bagi tersangka dalam perkara pidana.

Sistem hak asasi manusia mencakup didalamnya ranah administrasi peradilan, yang memuat beberapa prinsip, yaitu peradilan yang adil (Fair Trial), Indepedensi Pengadilan (Indepence Judiciary), dan pemulihan secara efektif (Effective Remedies). Prinsip-prinsip tersebut tidak hanya berlaku untuk peradilan pidana umum maupun peradilan pidana militer. ${ }^{12}$ Dalam Undang-Undang Nomor 39 Tahun 1999, lebih menekankan penyelidikan dibanding penyidikan. Yang dimana, HAM memiliki kewenangan untuk menyelidiki pelanggaran HAM, yaitu: penyelidikan dan pemeriksaan terhadap peristiwa yang timbul dalam masyarakat yang berdasarkan sifat atau lingkupnya patut diduga terdapat pelanggaran hak asasi manusia. ${ }^{13}$

a. Penangkapan

Pelanggaran HAM paling banyak dari penangkapan sampai penahanan ialah pada saat penahanan. Penangkapan, penahanan, penggeledahan, penyitaan, penyadapan dan pemeriksaan surat mempunyai dampak mengurangi kebebasan orang, dengan demikian merupakan pembatasan terhadap hak-hak asasi manusia. Mengenai penangkapan tersebut, telah diatur dalam Pasal 11 Undang-Undang Nomor 26 Tahun 2000 tentang Pengadilan HAM.

b. Penahanan

Dibanding dengan ketentuan tentang penahanan dalam HIR, maka ketentuan dalam KUHAP lebih menjamin hak asasi manusia. Yang dimana, penahanan ini diatur juga didalam Pasal 12 sampai Pasal 17 Undang-Undang Nomor 26 Tahun 2000. Akan tetapi, penahanan dalam KUHAP tidak sesuai dengan Konvensi Internasional yang sudah diratifikasi Indonesia. Berdasarkan Pasal 9 ICCPR (International Covenant on Civil and Political Rights) menentukan bahwa segera (promptly) tersangka ditangkap harus secara fisik dibawa ke hakim untuk dilakukan penahanan. ${ }^{14}$

c. Penggeledahan

Salah satu asas dasar hak asasi manusia adalah perlindungan atas ketentraman di dalam tempat kediaman orang. ${ }^{15}$ Pelanggaran atas asas itu (mengganggu tempat kediaman orang) merupakan suatu pelanggaran yang serius. Pasal 12 Deklarasi Umum Hak Asasi Manusia menjamin kentetraman tempat kediaman orang, Pasal itu berbunyi: "Tiada seorang pun jua dapat diganggu dengan sewenang-wenang dalam urusan perorangannya, keluarganya, rumah

\footnotetext{
${ }^{12}$ Dinda Dinanti, Yuliana Yuli W, 2015, Perlindungan Hukum Atas Hak-Hak Tersangka Pada Proses Penyidikan Perkara Pidana Dalam Perspektif Hak Asasi Manusia, Jurnal Magister Hukum Universitas Pembangunan Nasional veteran Jakarta.

${ }^{13}$ Pasal 89 ayat (3) Undang-Undang Nomor 39 Tahun 1999, Lembaran Negara (LN) Tahun 1999 Nomor 165 Tambahan Lembaran Negara (TLN) 3886 tentang Hak Asasi Manusia.

14 Andi Hamzah, Perlindungan Hak-Hak Asasi Manusia Dalam Hukum Acara Pidana Perbandingan Dengan Beberapa Negara, Jakarta: Universitas Trisakti, 2010, hlm. 73

${ }^{15}$ Ibid, hlm. 91.
} 
tangganya atau hubungan surat menyuratnya atas kehormatan dan nama baiknya. Setiap orang berhak mendapat perlindungan undang-undang terhadap gangguan-gangguan atau pelanggaran-pelanggaran demikian." "Tidak seorang pun dapat dikenakan penangkapan, penahanan, penggeledahan dan penyitaan selain atas perintah tertulis oleh kekuasaan yang sah dalam hal dan menurut cara yang diatur dalam undang-undang." 16

d. Penyitaan

Penyitaan merupakan pembatasan terhadap hak asasi manusia terhadap hak milik. Tindakan penyitaan merupakan suatu pengambil alihan dan penguasaan milik orang. Dengan sendirinya, hal itu bertentangan dengan hak asasi manusia yang pokok, yaitu merampas penguasaan atau milik orang. Salah satu yang dilindungi oleh The Universal Declaration of Human Rights ialah hak milik. Hal tersebut tertuang dalam Pasal 17 ayat (1) dan (2) sebagai berikut: every one has the right to own property alone as well as in association with others." (Setiap orang berhak mempunyai milik baik sendiri maupun bersama-sama dengan orang lain).

\section{B. Faktor-faktor Penghambat Dalam Perwujudan Hak-Hak Tersangka Dalam Proses Pemeriksaan Penyidikan Di Indonesia}

Hak adalah sesuatu yang dapat di peroleh oleh setiap individu, jika kita berbicara tentang hak apa saja yang di dapatkan tersangka dalam proses pemekrisaan dan apa hambatan apa saja pada hak-hak yang harus mereka peroleh saat pemeriksaan, Mengenai hak dan kedudukan tersangka atau terdakwa yang diatur dalam Bab VI KUHAP, dapat dikelompokan sebagai berikut:

a. Hak Tersangka atau Terdakwa Segera mendapat Pemeriksaan Penjabaran prinsip peradilan sederhana, cepat dan biaya ringan dipertegas dalam Pasal 50 KUHAP, yang memberi hak yang sah menurut hukum dan undang-undangg kepada tersangka atau terdakwa:

1. Berhak segera untuk diperiksa oleh penyidik;

2. Berhak segera diajukan ke siding pengadilan;

3. Berhak segera diadili dan mendapat putusan pengadilan (speedy trial right)

b. Hak untuk Melalukan Pembelaan Untuk mempersiapkan hak pembelaan tersangka atau terdakwa, undang-undang menentukan beberapa Pasal (Pasal 51 sampai Pasal 57).

c. Hak Tersangka atau Terdakwa yang Berada Dalam Penahanan Hak-hak terdakwa yang telah dibicarakan adalah hak yang berlaku pada umumnya terhadap tersangka atau terdakwa baik yang berada dalam penahanan atau diluar penahanan. Disamping hak-hak tersangka atau terdakwa yang umum tersebut, undang-undang masih memberi lagi hak yang melindungi tersangka atau terdakwa yang berada dalam penahan.

${ }^{16}$ Pasal 7 Undang-Undang Nomor 4 Tahun 2004 Lembaran Negara (LN) Tahun 2004 Nomor 8 tentang Kekuasaan Kehakiman. 
d. Hak Terdakwa di Muka Persidangan Pengadilan Disamping hak yang diberikan pada tersangka dan terdakwa selama dalam tingkat proses penyidikan dan penuntutan, KUHAP juga memberi hak kepada terdakwa selama proses pemeriksaan persidangan pengadilan.

e. Hak Terdakwa Memanfaatkan Upaya Hukum Seperti yang diketahui, undangundang memberi kemungkinan bagi terdakwa yang dijatuhi hukuman untuk menolak atau tidak menerima putusan yang dijatuhkan pengadilan.

f. Berhak Menuntut Ganti Rugi dan Rehabilitasi KUHAP memberi hak kepada tersangka untuk menuntut ganti rugi dan rehabilitas. Salah satu hak tersangka yang sering dipermasalahkan adalah hak untuk memilih menjawab atau tidak menjawab pertanyaan yang diajukan penyidik, penuntut umum dan hakim. Yang banyak dipermasalahkan di tingkat penyidikan adalah apakah tersangka berhak untuk menjawab pertanyaan penyidik. Di Inggris berlaku hak untuk tidak menjawab, bahkan sangat ketat. Pemeriksa harus mulai dengan mengatakan kepada the suspect bahwa ia mempunyai hak untuk diam, tidak menjawab pertanyaan. ${ }^{17}$

Tapi di dalam prakteknya terkadang hak tersebut oleh terdakwa dan kadang juga di abaikan dalam hal ini jelas terdakwa tidak mendapatkan haknya dan juga dalam hal ini terjadi hambatan-hambatan yang terjadi sampe hak terdakwa tidak terpenuhi dan juga seperti yang kita ketahui hak terdakwa sudah jelas tertera dalam pasal 50 KUHAP, Hambatan dalam proses penyidikan yakni salah satunya adanya penyidik yang belum bertindak secara profesional didalam melakukan penyidikan, sehingga melahirkan perbuatan-perbuatan yang bertentangan dengan hak asasi manusia. menuturut penulis bahwa ada beberapa faktor penghambat dalam penerapan hak asasi manusia (HAM), yang terjadi pada proses penyidikan diantaranya :

a. Dalam proses interogasi (pemeriksaan) terhadap tersangka terkait dengan kasuskasus tertentu seperti kasus pemerkosaan dan kasus kesusilaan, perzinahan, pencabulan dan kasus Kekerasan dalam Rumah Tangga (KDRT) yang masih sulit untuk didapatkan keterangan. Hal ini disebabkan oleh kecenderungan tersangka enggan atau merasa malu untuk menceritakan aibnya kepada penyidik sehingga membuat kasus ini sulit untuk disidik karena tidak adanya kejujuran dan transparansi dari tersangka. Selain itu juga, tersangka enggan untuk memberikan keterangan secara jujur, karena hal itu akan memberatkan atau merugikan bagi dirinya di muka persidangan sehingga penyidik sulit untuk mengorek keterangan yang jujur atau sebenar-benarnya dari tersangka;

b. Saat penyidik melakukan pemeriksaan terhadap tersangka, penyidik juga mengalami kesulitan untuk mendapatkan keterangan dari tersangka karena tersangka berbelit-belit di dalam memberikan keterangan sehingga membuat proses penyidikan berlangsung lama dan lamban;

c. Tersangka atau terdakwa sakit secara tibatiba sehingga dengan keadaan yang demikian menimbulkan hambatan di dalam proses penyidikan karena bisa mengulur atau menunda proses penyidikan. Hal ini cenderung menyebabkan

${ }^{17}$ Perlindungan Hukum Atas Hak-Hak Tersangka Pada Proses Penyidikan Perkara Pidana Dalam Perspektif Hak Asasi Manusia Dinda Dinanti, Yuliana Yuli W Magister Hukum Universitas Pembangunan Nasional "Veteran" Jakarta. 
proses penyidikan berlangsung lebih lama karena harus menunggu tersangka sembuh baru penyidikan bisa dilanjutkan kembali;

d. Ruang gerak penyidik menjadi terbatas di dalam mengungkap suatu permasalahan, karena seseorang tidak boleh dianggap bersalah sebelum adanya putusan dari pengadilan yang memiliki kekuatan hukum tetap;

e. Selain itu juga, Kurang efektifnya pengembangan kualitas sistem pengawasan dan kontrol dari instansi terkait serta kurangnya peningkatan profesionalitas dari para penegak hukum yang harus disertai dedikasi dan rasa pengabdian yang tinggi untuk menegakkan keadilan. Dalam hal ini termasuk pula mental dari para penyidik yang belum sepenuhnya memiliki sifat kemanusiaan tinggi karena masih membedakan yang lemah dan yang kuat dalam masalah ekonomi, jabatan atau pekerjaan;

f. Adanya sistem tebang pilih yang dilakukan aparat cenderung menyebabkan kredibilitas dari aparat penegak hukum menjadi rendah dimata masyarakat. Hal ini menyebabkan masyarakat kurang percaya terhadap lembaga penegak hukum seperti kepolisian dan pengadilan dalam menangani suatu kasus sehingga masyarakaat awam atau masyarakat yang kurang mengetahui hukum cenderung menyelesaikan kasusnya menggunakan hukum adat mereka masingmasing karena mereka menganggap berperkara di pengadilan cenderung bersifat prosedural, berbelit belit dan hasilnya sering tidak memuaskan para pihak atau putusannya sering tidak sesuai dengan nilai keadilan yang tumbuh pada hati sanubari masyarakat.

g. Kurangnya koordinasi dan dukungan dari aparat penegak hukum lainnya seperti polisi, jaksa, hakim dalam pemberian bantuan hukum cuma-cuma. Hal ini dapat dilihat dari jarangnya permintaan kepada advokat oleh aparat penegak hukum baik polisi maupun jaksa untuk memberikan bantuan hukum ketika ada klien yang tidak mampu secara ekonomi dihadapkan dengan perkara pidana dengan ancaman pidana 5 (lima) tahun lebih.

Penyidik lebih suka tersangka tidak didampingi oleh penasehat hukum dan hal ini biasanya diligitimasi dengan pernyataan klien yang tidak mau didampingi oleh advokat ketika disidik, kalaupun klien tersebut mau didampingi oleh advokat, biasanya aparat penegak hukumnya menunjukkan sikap kurang bersahabat dengan advokat yang mendampinginya.Apabila sungguh-sungguh berlandaskan pada asas praduga tidak bersalah (APTB) dan asas persamaan kedudukan dalam hukum (APKDH), kendala yang dimaksud seharusnya tidak ada, sebab jelas bahwa setiap tersangka dan terdakwa dalam proses peradilan pidana, wajib mendapatkan hak-haknya tanpa kecuali dan tanpa perbedaan. Pandangan check and balance, pemisahan kekuasaan, kebebasan atau indepedensi peradilan, due process of low, yang merupakan landasan vital dan rechtstaat (Negara hukum) belum dibahas secara mendalam oleh pihakpihak yang kompeten sehingga belum ada penyelesaian yang konkret. Hal ini menyebabkan jaminan dan perlindungan hak asasi tersangka dan terdakwa menghadapi situasi yang kurang menguntungkan, walaupun berbagai perbaikan sudah dimuat melalui peraturan-peraturan baru. Undang-Undang No. 8 Tahun 1981 Tentang Hukum Acara Pidana. Berdasarkan hasil penelitian terhadap pasalpasal dalam Undang-Undang No. 8 Tahun 1981 serta peraturan pelaksanannya (telah diuraikan dalam bab sebelumnya) mengenai penjabaran asas praduga tidak bersalah (APTB) hubunganya dengan asas persamaan kedudukan dalam hukum (APKDH), ternyata secara yuridis masih belum menunjang ke arah penerapan asas praduga tidak bersalah (APTB) dan asas persamaan 
kedudukan dalam hukum (APKDH) secara harmonis. Disamping adanya alasan yuridis sebagai faktor penghambat, hasil penelitian Hukum Tata Negara (Mahfud M.D) menyatakan bahwa produk Hukum, pelakasanaan dan perkembangan hukum diwarnai oleh konfigurasi politik. Demikian pula didalam proses peradilan pidana masih banyak kendala yang berkaitan dengan kepentingan politik, sehingga sering terjadi proses pidana yang bersifat rahasia,samar,dan tidak responsif.Sistem peradilan pidana seharusnya merupakan perwujudan dan kekuasaan kehakiman yang merdeka dan mandiri (menurut Pasal 24 Undang-Undang 1945). Selama periode orde lama dan orde baru, subsitem dan sistem peradilan pidana masih berada dibawah pengaruh kekuasaan eksekutif. Keadaan ini memungkinkan adanya campur tangan pada pelaksanaan sistem peradilan pidana antara lain terganggunya keharmonisan penerapan asas praduga tidak bersalah (APTB) dengan asas persamaan kedudukan dalam hukum (APKDH) yang akan menimbulkan kecemburuan dan ketakpercayaan masyarakat pencari keadilan, antara lain merajalelanya tindakan main sendiri. Kurang efektifnya pengembangan kualitas sistem pengawasan dan kontrol dari instansi terkait serta kurangnya peningkatan profesionalitas dari para penegak hukum yang harus disertai dedikasi dan rasa pengabdian yang tinggi untuk menegakan keadilan. Dalam hal ini termasuk pula mental dari para pengacara yang seharusnya memiliki sifat kemanusiaan tinggi tidak membedakan yang lemah dan yang kuat dalam masalah ekonomi jabatan atau pekerjaan.Selain itu, kenyataan menunjukan bahwa kesadaran hukum dari masyarakat merupakan indikataor yang penting untuk menunjang terselenggaranya proses peradilan pidana yang berkualitas.

Di dalam praktik penegakan supremasi hukum masih belum ada kerja sama yang baik antara penegak hukum, masyarakat dan pemerintah. Untuk menjamin penghormatan dan perlindungan HAM dalam proses peradilan pidana, fungsi penasihat hukum sangat penting sebagai pendamping tersangka dan terdakwa agar mempertahankan hak-haknya. Hal ini tidak terlepas dari keberadaan perundangundangan yang mengatur kedudukan, fungsi dan peran penasihat hukum agar dapat melaksanakan tugas dengan baik serta berdedikasi dan berintegritas tinggi serta tidak hanya bertindak demi kemenangan kliennya, tetapi harus berfikiran luas demi kepentingan keadilan serta kepentingan masyarakat secara nasional. Berkaitan dengan hal tersebut mengenai masalah dan kendala yang sering timbul dalam proses penyidikan, permasalahan itu acap kali terjadi ketika proses hukum formil itu dioperasionalkan, serta hukum materiil itu diaplikasikan dalam penanganan perkara, hukum formil, (hukum acara), dan hukum materiil (materi ketentuan hukumnya).

Aplikasi hukum formil itu mulai dari pemanggilan, pemeriksaaan, penagkapan, penahanan, penyitaan,penggeledahan, penahanan lanjutan, dan mengungkap kebutuhan hukum materiilnya. Mengungkap kebutuhan hukum materiil tersebut misalnya pembuktian, kecermatan, dan ketelitian pembuatan berita acara, termasuk menempatkan kata-kata yang tidak tepat, yang setidak-tidaknya mempengaruhi kualitas pembuktian perkara itu sendiri. Pembahasan dalam subbab ini adalah dalam rangka mengungkapkan permasalahan yang sering terjadi yang dapat saja karena telah diketahui sebelumnya, maupun yang belum diketahui permasalahan sebelumnya, dengan pembahasan permasalahan-permasalahan itu setelah diketahui sebab-sebab terjadinya permasalahan atau kesalahan-kesalahan itu segera dapat ditinggalkan, dengan harapan identifikasi permasalahan itu akan mampu memberi pencerahan, atau setidak-tidaknya akan membawa pencerahan wajah hukum yang diharapkan bangsa Indonesia pada uraian ini juga sekaligus penulis berusaha memberikan pembelajaran hukum kepada siapa saja secara terbuka, agar target kesadaran hukum masyarakat itu 
segera meningkat, karena penulis yakin bahwa tidak harus seorang berlatar belakang pendidikan hukum saja yang hanya boleh tau masalah ini. Permasalahan munculkan semenjak awal proses perkara itu sedang berjalan hingga proses hukum itu dikehendaki berakhir oleh para pihak secara sukarela, atau karena berakhirnya disebabkan sebuah proses hukum yang wajar. ${ }^{18}$

\section{KESIMPULAN}

Dalam melindungi tersangka dari tindakan penyidik yang sewenang-wenang maka dalam KUHAP diatur mengenai perlindungan hak-hak tersangka dalam proses penyidikan perkara pidana. Hak-hak tersebut diatur dalam Bab VI (Pasal 50 sampai dengan Pasal 68) Undang-Undang Nomor 8 Tahun 1981. Perlindungan hukum bagi tersangka dari tindakan yang menyangkut hak asasi tersangka oleh penyidik sangatlah penting. Terutama bagi tersangka yang awam terhadap hukum akan kesulitan untuk meminta maupun menuntut hak-hak yang dimilikinya, oleh karena itu penyidik berkewajiban memberitahukan hak tersangka dalam memperoleh perlindungan hukum.

Untuk melindungi tersangka dari tindakan penyidik yang sewenang-wenang maka dalam KUHAP diatur mengenai perlindungan Hak Asasi Manusia khususnya terkait dengan hak tersangka dan terdakwa. Meskipun hak-hak tersangka sudah diatur dengan jelas dalam KUHAP namun dalam praktiknya seringkali terjadi pelanggaran dan hambatan dalam proses penyidikan terhadap hak-hak tersangka yang dilakukan oleh aparat penegak hukum terkait. Perlindungan hukum bagi tersangka dari tindak kekerasan oleh penyidik sangatlah penting. Terutama bagi tersangka yang awam terhadap hukum akan kesulitan untuk meminta maupun menuntut hak-hak yang dimilikinya, oleh karena itu untuk mewujudkan hak-hak tersangka/terdakwa penyidik berkewajiban memberitahukan secara rinci mengenai hak-hak yang dimiliki oleh tersangka khususnya memberitahukan hak tersangka dalam memperoleh perlindungan hukum, berhak mendapat bantuan hukum dan hak-hak lainnya, Dalam KUHAP sudah diatur mengenai kewajiban penyidik untuk memberitahukan hak-hak yang dimiliki tersangka. Agar hambatan-hambatan dalam pemeriksaan penyidikan tidak lagi terjadi dan lebih memperhatikan hak-hak tersangka dan terdakwa.

\section{SARAN}

Penyidik perlu meningkatkan profesionalisme, yaitu bekerja sesuai dengan aturan dan ketentuan yang berlaku, tidak melakukan pelanggaran berupa tekanan atau paksaan baik fisik maupun psikis kepada tersangka selama proses pemeriksaan (penyidikan) serta melaksanakan asas praduga tak bersalah dan asas persamaan kedudukan dalam hukum. Terus dibinanya kesadaran penyidik tentang pentingnya perlindungan terhadap hak-hak asasi manusia, sehingga penyidik mengetahui bahwa hak asasi manusia merupakan suatu keadaan hakiki yang tidak dapat diganggu dan harus dihormati serta dijunjung tinggi, kecuali karena adanya suatu kondisi yang sangat memaksa yang tidak dapat dihindari lagi. Walaupun begitu tetap harus memperhatikan ketentuan-ketentuan yang ada, yang mengatur tentang pengecualian tersebut.

\footnotetext{
${ }^{18}$ Nolfan Hibata, Hak-Hak Tersangka Sebagai Perwujudan Hak Asasi Manusia Dalam Proses Pemeriksaan Di Tingkat Penyidikan, 2016 Jurnal lex et societatis, $\underline{\text { Home }}>\underline{\text { Vol 4, No } 6}$ $\underline{(2016)}>$ Hibata.
} 
Untuk menghindari hambatan-hambatan yang terjadi di tingkat penyidikan, penyidik harus memeritahukan kepadanya tentang hak mendapat bantuan hukum, dan hak lain sebagainya. Dan perlu ditingkatkannya profesionalisme penyidik dalam menangani kasus yang ada dengan menggunakan teknik-teknik yang efektif dan efisien sehingga kekerasan itu tidak diperlukan lagi, setidak-tidaknya kekerasan tersebut bisa dikurangi.

\section{DAFTAR PUSTAKA}

B.N. Marbun, Kamus Hukum Indonesia Edisi Kedua Direvisi, 2009, Cetakan 1, Jakarta: Pustaka Sinar Harapan.

Dinda Dinanti, Yuliana Yuli W, Perlindungan Hukum Atas Hak-Hak Tersangka Pada Proses Penyidikan Perkara Pidana Dalam Perspektif Hak Asasi Manusia, Jurnal Magister Hukum Universitas Pembangunan Nasional "Veteran" Jakarta.

Gerson W. Bawengan, 1977, Penyidikan Perkara Pidana dan Teknik Interogasi, Jakarta: PT. Pradnya Paramita.

Hamzah. Andi, 2010, Perlindungan Hak-Hak Asasi Manusia Dalam Hukum Acara Pidana Perbandingan Dengan Beberapa Negara, Jakarta: Universitas Trisakti.

Joan Nelson. Samuel P. Huntington, 1994, Partisipasi Politik Di Negara Berkembang, Jakarta. Rineka Cipta.

Mulyadi. Lilik, 2001, Hukum Acara Pidana Indonesia Suatu Tinjauan Khusus Terhadap Surat Dakwaan, Ekssepsi Putusan Hakim, Bandung: Citra Aditya Bakti.

Nolfan Hibata, Hak-Hak Tersangka Sebagai Perwujudan Hak Asasi Manusia Dalam ProsesPemeriksaan Di Tingkat Penyidikan, 2016 Jurnal Lex Et Societatis, $\underline{\text { Home }}>\underline{\text { Vol 4, No6 (2016) }}>$ Hibata.

Prodjodikoro. Wiryono, 1967, Hukum Acara Pidana di Indonesia, Penerbit Sumur Bandung, Jakarta.

Rukmini. Mien, 2003, Perlindungan HAM Melalui Asas Praduga Tidak Bersalah dan Asas Persamaan Kedudukan dalam Hukum pada Sistem Peradilan Pidana Indonesia, Bandung: Alumni.

Sujatmoko. Andrey, 2015, Hukum HAM dan Hukum Humaniter, Jakarta: PT RajaGrafindo Persada,

Tioneni Sigiro, 2018, Pelaksanaan Asas Akusator Oleh Polri Dalam Penyidikan Tindak Pidana Di Polres Dairi, Jurnal Fakultas Hukum Universitas Sumatera Utara Medan.

\section{Peraturan Perundang-Undangan}

Undang-Undang Dasar 1945

Kitab Undang-Undang Hukum Acara Pidana (KUHAP)

Undang-undang Nomor 2 Tahun 2002 tentang Kepolisian. 
Undang-Undang Nomor 39 Tahun 1999 tentang Hak Asasi Manusia.

Undang-Undang Nomor 18 Tahun 2003 Lembaran Negara (LN) Tahun 2003 Nomor 48 Tambahan Lembaran Negara (TLN) Nomor 4288 Tentang Advokat.

Undang-Undang Nomor 39 Tahun 1999, Lembaran Negara (LN) Tahun 1999 Nomor 165 Tambahan Lembaran Negara (TLN) 3886 tentang Hak Asasi Manusia. 